\title{
Analysis of Water Quality Using Physicochemical Parameters of Boreholes Water Taken from Areas Around Dala Hills, Northwestern Nigeria
}

\author{
Ado Garba Bataiya ${ }^{1, ~ *, ~ H a b i b a ~ M u h a m m a d ~}{ }^{2}$, Sallau Ibrahim Ahmad ${ }^{2}$, Jafaru Muazu $^{3}$ \\ ${ }^{1}$ Department of Chemistry, School of Science Education, Sa'adatu Rimi College of Education, Kumbotso, Nigeria \\ ${ }^{2}$ Department of Biology, School of Science Education, Sa'adatu Rimi College of Education, Kumbotso, Nigeria \\ ${ }^{3}$ Department of Geography, College of Advance and Remedial Studies, Tudunwada, Nigeria
}

Email address:

adogarbataiyaali@gmail.com (A. G. Bataiya)

${ }^{*}$ Corresponding author

\section{To cite this article:}

Ado Garba Bataiya, Habiba Muhammad, Sallau Ibrahim Ahmad, Jafaru Muazu. Analysis of Water Quality Using Physicochemical Parameters of Boreholes Water Taken from Areas Around Dala Hills, Northwestern Nigeria. American Journal of Water Science and Engineering. Vol. 3, No. 6, 2017, pp. 80-83. doi: 10.11648/j.ajwse.20170306.13

Received: August 29, 2017; Accepted: November 20, 2017; Published: December 27, 2017

\begin{abstract}
Drinking water quality is of fundamental importance to human physiology and the durability of humanity depends very much on it's availability. The present research was conducted purposely to assess the quality of ground water from areas located around Dala hills. Five samples were collected from Rijiya Biyu $\left(D_{1}\right)$, Kantudu $\left(D_{2}\right)$, Makwalla $\left(D_{3}\right)$ Kabawa $\left(D_{4}\right)$ and Dala $\left(\mathrm{D}_{5}\right)$ for physicochemical analysis. The physico-chemical parameters analyzed are $\mathrm{pH}$, electrical conductivity, temperature, turbidity, colour, odour, total suspended solid (TSS), Suspended solids (SS), Total dissolved solids (TDS), Calcium, magnesium, chloride, Total Hardness, Alkalinity and free $\mathrm{CO}_{2}$. The result obtained shows that the water studied has a mean value of $1.6 \mathrm{NTU}$ for turbidity, 8.14 for $\mathrm{pH}, 1512.2 \mu \mathrm{S} / \mathrm{cm}$ for electrical conductivity, $845 \mathrm{mg} / \mathrm{L}$ for total dissolved solids. Total suspended solids has a mean value of $845 \mathrm{mg} / \mathrm{L}$, Suspended solids $0.00 \mathrm{mg} / \mathrm{L}$, Temperature $28.2^{\circ} \mathrm{C}$, colour 5 Hazen, total hardness $149.96 \mathrm{mg} / \mathrm{L}$, alkalinity $51.4 \mathrm{mg} / \mathrm{L}$, chloride $31.08 \mathrm{mg} / \mathrm{L}$ free $\mathrm{CO}_{2} 72 \mathrm{mg} / \mathrm{L}$, Calcium $62.37 \mathrm{mg} / \mathrm{L}$ and $92.99 \mathrm{mg} / \mathrm{L}$ for magnesium. As the result indicated all the physicochemical parameters are within the recommended levels set by World Health Organization (WHO) and Nigerian Standard for Drinking Water Quality (NSDWQ) except for conductivities at all the samples site, and magnesium at $\mathrm{D}_{1}, \mathrm{D}_{2}$, and $\mathrm{D}_{3}$.
\end{abstract}

Keywords: Dala Hills, Water Quality, Contamination, Suspended Solid, Total Hardness

\section{Introduction}

Water is extremely essential for survival of all living organisms. The quality of water is vital concern for mankind since it is directly linked with human welfare. The ground water is believed to be comparatively much clean and free from pollution than surface water [1]. Groundwater is the main source of water supply in most rural communities in Africa. It has good microbiological and biological properties in general as such requires minimal treatment [2]. The determination of groundwater quality for human consumption is important for the wellbeing of the consumers due to population, growth. According to [3] groundwater quality depends to some extent, on its chemical composition which may be affected by natural anthropogenic factors. It was reported by [4] that, the rate of discharge of pollutants into the environments, which ultimately find their way into the water bodies is higher than the rate of purification [4] and could be due to rapid urbanization, industrialization, population growth as well as geological factors [4].

Groundwater is the main source of water used for domestic and agricultural purposes in Dala. The water supply for domestic and agricultural purposes in the study area is directly sourced from groundwater without any chemical treatment and the fear of pollution has become a cause for major concern [7].

This research is aimed at assessing the physicochemical 
parameters in ground water samples from five sampling point around Dala hills in Dala Local Government Area of Kano State to examined the quality of physicochemical parameters and to compare with the Standards for Drinking Water of WHO and NSDWQ.

\section{Materials and Methods}

\subsection{Description Area}

Dala hill is a hill located in Dala. It has 534 meters $(1,753$ feet) high. [5]. There are steps on the hill which has 999 footsteps. Dala is densely populated local government area and is located in the northwest part of the Kano metropolis. It lies between $12^{\circ} 0 \mathrm{IN}$ and $8^{0} 29 \mathrm{E}$ it has an area of $19 \mathrm{~km}^{2}$ and a population of 418,777 at the 2006 census. It is thus the largest local government area in Nigeria [6].

\subsection{Sampling Techniques}

Five samples of borehole water were collected from Rijiya biyu, Kantudu, Makwalla, Kabawa and Dala around Dala hills, Dala local government of Kano state using clean new polyethene plastic containers which were covered with Black polyethene bags to prevent growth of Algae [4]. The $\mathrm{pH}$, temperature and conductivity, were determined immediately after sampling and the sample was stored at a temperature below $4^{\circ} \mathrm{C}$, this is to prevent the growth of microorganisms as reported by [4].

\subsection{Physicochemical Analysis}

\subsubsection{Electrical Conductivity Measurement}

Conductivities of the water samples were measured using a digital conductivity meter (HARCH Model) [4]. The meter was switched on and then standardized using $0.1 \mathrm{~N} \mathrm{KCl}$ at $25^{\circ} \mathrm{C}$. The electrode was then immersed into the water sample and conductivity reading of each sample was recorded [4].

\subsection{2. pH Measurement}

The $\mathrm{pH}$ was measured using a digital $\mathrm{pH}$ meter (HARCH SENSION) [4]. The meter was switched on and was allowed to warm for 5 minutes. It was then standardized with a buffer solution. The meter was then immediately introduced into the water sample and measurement was taking after a stable reading was taken. The electrode was then rinsed with deionized water before taken another measurement [4].

\subsubsection{Turbidity Measurement}

The turbidities of the water samples were measured using a digital turbidity meter (2100AN HARCH Model). The meter was standardized with a clean deionized water, and this was introduce into the water samples. The turbidity reading of each sample was then recorded [4].

\subsubsection{Determination of Total Dissolved Solid}

The total dissolved solid was determined using a Conductivity meter, the programme menu of the Conductivity meter was switched to total dissolved solid, 100 $\mathrm{cm}^{3}$ of the sample was measured into the beaker and the electrode was introduced into the sample. The results of total dissolved solid were displayed and recorded [4]. Similarly, gravimetric method was also used to determine the Total Dissolved Solid by evaporation in an oven at $200^{\circ} \mathrm{C}$ for $2 \mathrm{hrs}$. This is to ascertain the accuracy of the above mentioned method by comparing the two results no significant difference was recorded only that it has more time consuming as reported by [4].

\subsubsection{Determination of Total Hardness}

$10 \mathrm{~cm}^{3}$ of water sample was pipetted into a conical flask. 1 $\mathrm{cm} 3$ of buffer solution $(\mathrm{NH} 4 \mathrm{Cl})$ of $\mathrm{pH}=10$ and 3 drops of Erichrome black $\mathrm{T}$ indicator were added to the flask. The mixture was then titrated with 0.0IM EDTA (ethyl diammine tetra acetic acid) until the color changed from wine red to blue. The procedure was repeated two more times to obtain the average titer value [4].

\subsubsection{Determination of Alkalinity}

$100 \mathrm{~cm}^{3}$ of Sample was taken followed by $2-3$ drops of phenolphthalein indicator and the color change was observed followed by titrating with $0.1 \mathrm{~N} \mathrm{HCl}$ until the color changed from pink to colorless [4].

\subsubsection{Chloride Content}

It was determined by Mohr's method using silver nitrate as titrant and potassium chromate solution as indicator [7].

\subsubsection{Calcium Hardness}

Calcium hardness was determined using EDTA method with murexide (ammonium purpate) as indicator [7].

\subsubsection{Temperature}

The temperatures of the samples were measured at the point of collection using mercury in glass thermometer [7].

\section{Result}

The result of various physicochemical parameters recorded during present study at all the five sampling are presented in Table 1 below. The results obtained were analyzed and compared with the World Health Organization (WHO) and Nigerian standard for drinking water quality (NSDWQ).

Table 1. Result of Physicochemical Analysis.

\begin{tabular}{lllllll}
\hline S/N & Parameter & D1 & D2 & D3 & D4 & \\
\hline & Turbidity (NTU) & 0.00 & 4.00 & 1.00 & 2.00 & 8.40 \\
& pH & 8.00 & 8.20 & 100 & 8.00 \\
& EC $(\mu \mathrm{S} / \mathrm{Cm})$ & 1545.00 & 1669.00 & 1278.00 & 1178.00 \\
& TDS $(\mathrm{mg} / \mathrm{l})$ & 764 & 842 & 1060 & 618 \\
\hline
\end{tabular}




\begin{tabular}{lllllll}
\hline S/N & Parameter & D1 & D2 & D3 & D4 & D5 \\
\hline & SS $(\mathrm{mg} / \mathrm{l})$ & 0.00 & 0.00 & 0.00 & 0.00 & 0.00 \\
TSS $(\mathrm{mg} / \mathrm{l})$ & 764 & 842 & 1060 & 618 & 941 \\
Temperature $\left({ }^{\circ} \mathrm{C}\right)$ & 28.4 & 27.2 & 26.7 & 26.7 & 27.0 \\
Odour $(-)$ & Unobj & Unobj & Unobj & Unobj & Unobj \\
Colour (Hazen) & 5 & 5 & 5 & 5 & 5 \\
TH (mg/l) & 134.67 & 179.57 & 179.68 & 125.69 & 130.19 \\
Alkalinity (mg/l) & 54.00 & 53.50 & 55.50 & 43.00 & 51.00 \\
Chloride (mg/l) & 23.19 & 23.15 & 31.07 & 34.55 & 42.44 \\
Free $\mathrm{CO}_{2}(\mathrm{mg} / \mathrm{l})$ & 36.00 & 96.00 & 98.00 & 36.00 & 94.00 \\
Calcium (mg/l) & 32.45 & 50.47 & 41.46 & 100.94 & 86.52 \\
Magnesium (mg/l) & 11.22 & 129.10 & 138.22 & 51.75 & 43.67 \\
\hline
\end{tabular}

\section{Discussion}

The $\mathrm{pH}$ values of groundwater range from $8.00-8.40$ and falls within the WHO and NSDWQ permissible limit of 6.58.6. Hundred percent of analyzed samples have $\mathrm{pH}$ values higher 7.0. The TH values ranged from $130.19-179.68 \mathrm{mg} / \mathrm{L}$. based on $[4,8]$ classification, all the samples fall under the "moderate hard" class. The highest values was observed at $\mathrm{D}_{3}$ and the lowest at $\mathrm{D}_{5}$. The EC values range from 1178.00-1891.00 $\mu \mathrm{S} / \mathrm{cm}$. High EC values was observed at point $\mathrm{D}_{5}$ indicating the presence of high amount of dissolved inorganic substances in ionized form in water. The TDS values lie above the WHO and NSDWQ limits. The values varies from $618-1060 \mathrm{mg} / \mathrm{L}$ and high value was recorded at sampling point $\mathrm{D}_{3}$ and lowest at $\mathrm{D}_{4}$. In present study average value of total alkalinity varied from minimum of $43 \mathrm{mg} / \mathrm{L}$ at $\mathrm{D}_{4}$ to a maximum of $55.50 \mathrm{mg} / \mathrm{L}$ at $\mathrm{D}_{3}$, and were found within the permissible limit of $100 \mathrm{mg} / \mathrm{L}$ prescribed by $[9,10]$. The high alkalinity value indicates the presence of weak and strong base such as carbonates, bicarbonates and hydroxides in the water body. The concentrations of chloride varied between 23.15-42.44 $\mathrm{mg} / \mathrm{L}$ with minimum at $\mathrm{D}_{2}$ and maximum at $\mathrm{D}_{5}[9,10]$. According to $[9,10]$, the prescribed permissible limit of chloride is $250 \mathrm{mg} / \mathrm{L}$. Chloride concentrations in all the sampling point are within the prescribed limit.

The turbidity level in all the sample sites determined showed that they are within the recommended level of 5NTU [10] as shown in table 1 . The turbidity values of the study area ranged between $0.00-4.00 \mathrm{NTU}$ with high value at $\mathrm{D}_{2}$ and lowest at $\mathrm{D}_{1}$. The result shows temperature range between $26.7-28.4^{\circ} \mathrm{C}$. The colour of all the samples was found to be 5 hazen and fall within the permissible limit set by $[10]$.

The calcium values for the samples analyzed ranged from $32.45-100.94 \mathrm{mg} / 1$. the general acceptable limit of calcium in water is usually $75 \mathrm{mg} / 1$ whereas it's maximum permissible limit is $300 \mathrm{mg} / \mathrm{L}[10]$. The highest value was recorded at $D_{4}$, and lowest at $\mathrm{D}_{1}$. In the present study, the result shows that the magnesium in water samples varied between 43.67$138.22 \mathrm{mg} / \mathrm{L}$. The minimum acceptable limit of Magnesium in water is $50 \mathrm{mg} / \mathrm{L} .60 \%$ of the sample are above the recommended limit. The value of free $\mathrm{CO}_{2}$ ranges from $36.00-98.00 \mathrm{mg} / \mathrm{L}$, The maximum value of 98.00 and minimum value 36.00 were recorded at $\mathrm{D}_{3}$ and $\mathrm{D}_{1}, \mathrm{D}_{4}$ respectively. The result from the analysis shows that TSS values range from $618.00-1060.00 \mathrm{mg} / \mathrm{L}$. The high values was recorded at $\mathrm{D}_{3}$ and $\mathrm{D}_{4}$ has the lower value.

\section{Conclusion}

Contamination of groundwater has severe implications for public health, particularly in small communities and developing countries where groundwater is the only source of drinking water [11]. Conformation with physicochemical standard is of special interest because of the capacity of water to spread diseases within a large population. From the observation and results it can be concluded that the different studied parameters such as $\mathrm{pH}$, temperature, TDS, colour, turbidity, alkalinity, free $\mathrm{CO}_{2}, \mathrm{TH}$, TSS, odour, SS, and concentration of chloride and calcium were found to be within the permissible limit recommended by World Health Organization (WHO) and Nigerian Standard for Drinking Water Quality (NSDWQ), except for conductivities at all the samples site, and magnesium at $\mathrm{D}_{1}, \mathrm{D}_{2}$, and $\mathrm{D}_{3}$.

\section{Acknowledgements}

The authors are grateful to the management and staffs of Tamburawa water treatments plant, and Dr. Garba Alhaji Adamu, the Head of Department Science Laboratory Technology, Kano State Polytechnic, for their assistance throughout this research.

\section{References}

[1] Mohd, I. Haroon, S., Bhat, F. A. and Imran A. (2013) "Monitoring of Water Quality Parameters in Upper and Lower Reaches of Dudhganga Catchment, India". InTech Publishing Group http://dx.daorg 100. 5772/52846.

[2] Bernard Thole (2013) "Ground Water Contamination with Fluoride and Potential Fluoride Removal Technologies for East and Southern Africa" Intech Publishing Group http://dxdoi.ord100.5772/54985.

[3] Garba, A., Ekanem, E. O. and Garba, I. H. (2016). Quality Assessment of Groundwater from Hadejia Local Government Area of Jigawa state Nigeria. Bayero Journal of Pure and Applied Sciences, 9 (2): 258-262. 
[4] Saeed, M. D. and Mahmoud A. M. (2014). Determination of Some Physicochemical Parameters and Some Heavy Metals in Boreholes from Fagge LGA of Kano Metropolis Kano State Nigeria. World Journal of Analytical Chemistry, 2 (2): 42-46.

[5] "Kano" Encyclopedia Britannica. Encyclopedia Britannica Inc. 2007.

[6] Nigeria, US Embassy. “Amb Campbell's Speech" (2007). Speech of the Local Government Chairman Caretaker Committee (Alhaji Mahmud Sani Madaki) During the visit of the America Ambassador to Nigeria at G. G. C Dala on Saturday $2^{\text {nd }}$ June 2007. Us Embassy Nigeria. Retrieved 10 may 2016.

[7] Bernard, E. and Ayeni N, (2012). Physicochemical analysis of groundwater samples of Bichi Local Government Area of Kano State of Nigeria. world Environment, Vol. 2 No. 6, pp. 116-2119. doi: 10.5923/j.env.20120206.02.

[8] Roxanne J. and Tom S. (2012). Driving Water Quality Testing and Interpreting your Results Revised ed.

[9] NSDWQ (2007). Nigerian Standard for Drinking Water Quality. NIS 554, Son, Lagos, 30.

[10] WHO (2006) Guidelines for Drinking Water quality $3^{\text {rd }}$ Edition, WHO Press, Geneva, 398.

[11] Allamin, I. A., Borkoma, M. B., Joshua, R. and Machina, I. B. (2015). Physicochemical and Bacteriological Analysis of Well Water in Kaduna Metropolis Kaduna State. Open Access Library Journal 2:e1597. http://dx.org/10.4236oalib.1101597. 